\title{
Virtual communities in a secondary school - Discovering the internal grammar of video games
}

\author{
Laura Méndez ${ }^{1, *}$, María Ruth García-Pernía², Sara Cortés ${ }^{3}$ \\ 1Deptartment of Evolutionary and Educational Psychology, UNED, Spain \{Imendez@psi.uned.es\} \\ ${ }^{2}$ Deptartment of Philology, Documentation and Audiovisual Communication, University of Alcalá, Spain \\ \{mruth.garcia@uah.es\} \\ ${ }^{3}$ Department of Philology, Documentation and Audiovisual Communication, University of Alcalá, Spain \\ \{sara.cortesg@uah.es\} \\ Received on 31 August 2013; revised on 5 September 2013; accepted on 21 October 2013; published on 15 January 2014
}

DOI: $10.7821 /$ naer.3.1.2-10

\begin{abstract}
This study attempts to show how the creation of an innovative scenario, introducing video games and online communities as educational resources in the classroom, facilitates the development of new literacies in the context of participatory culture. The experience described was carried out during the 2010-2011 academic year in a secondary school located in Madrid. The workshop was organized using a social simulation video game, The Sims 3 , and the online community Play and Learn, created specifically for this project. From an ethnographic perspective, the article focuses mainly on analyzing what happened outside the game sessions, when the students became involved in the online community after interacting with the game in the classroom. The fact that they participated in a virtual conversational space (through a forum) serves to support the game and encourage reflection from all participants. The results show that social relationships were developed within the online community, where individual contributions proved especially important for group discussion. Participation made it possible for students to become aware of the speech and rules of the game and to improve the acquisition process of new literacies.
\end{abstract}

KEYWORDS: INNOVATION, NEW LITERACIES, ONLINE COMMUNITIES, VIDEO GAMES, ETHNOGRAPHY

\section{INTRODUCTION}

The purpose of this article is to show and analyze a new educational scenario where digital technologies and new forms of communication are present. More specifically, the article shows how an online community (Play and Learn) especially created for this project and a social simulation video game (The Sims 3) can be introduced in a high school classroom with the aim of generating new forms of learning and new literacies.

The introduction of widespread media such as an online community and a commercial video game in the classroom allowed us to establish connections between what happens inside and outside the school. In view of this, the need arises to enhance multiple literacy processes (Méndez, García-Pernía, \&

*To whom correspondence should be addressed:

Universidad de Alcalá

Aulario $\mathrm{M}^{\mathrm{a}}$ de Guzmán

Calle San Cirilo s/n. 28804

Alcalá de Henares. Madrid

Spain
Cortés, 2011; Olson \& Torrance, 2009; Wells, 1990) that will allow students to become active participants in these media, able to reconstruct the messages that they receive and to develop conscious knowledge from those messages. This process is dealt with in the context of a participatory culture that considers people to be not only consumers and receivers of messages but also producers and creators of content targeting multiple audiences. By producing information and reflecting upon it, students become dynamic agents of the media, aware of the elements that define language and integrated into a community of users that share the same communication code.

The overall aim of this paper is to describe and examine how a group of adolescents become aware of a video game language and its grammar. This was done through an analysis of their participation in the online community, used to share their experiences with the game The Sims 3. Our analysis will explore the representations and meanings built through dialogue in the forum. Two aspects are of special interest to us: a) Their ideas about the game and the elements which define its genre; and b) the shared representations of the problems encountered during the game along with the joint identification of strategies to solve them. This analysis will allow us to conclude that the use of a social network to support the use of video games in the classroom enhances the results obtained in other studies (Méndez, Lacasa, \& García-Pernía, 2013) about the acquisition of literacy within the framework of a participatory culture.

\section{THEORETICAL FRAMEWORK}

Figure 1 shows the ideas that sustain the analysis of the data presented in this paper. First, a need exists to approach the concept of online community understood as the virtual scenario that allowed students to actively participate and become producers of new types of speeches (Jenkins, Clinton, Purushotma, Robison, \& Weigel, 2009). This context allows us to analyze game grammars and their language to discover how players face them. Second, it is important to look into the game both internally and externally, to know this tool from its internal grammar taking into account its content and design, on the one hand, and to identify the challenges that students tried to solve and how they shared with other online community members (external grammar) appropriate strategies to address each problem, on the other. 


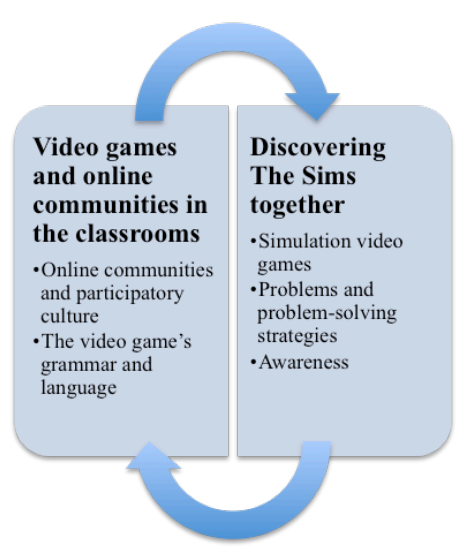

Figure 1. The online community and the video game in an educational context

\subsection{Video games and online communities in classrooms: New ways of learning}

Interactive entertainment (social networks, forums, chats, blogs...) and video games are cultural objects that have become part of people's everyday habits, transforming the society where they live. In this society, people communicate through the network, making the boundaries between transmitters and receivers -or, differently expressed, between authors and viewers- far more diffuse. Therefore, it is interesting to see how new media are present not only in entertainment but also in the classroom, because our intention is to delve into their language, ways of expression and the knowledge that derives from their use.

\subsubsection{Online communities in the context of a participatory culture}

The participatory culture (Jenkins, 2006) provides the theoretical framework to approach the online environment using it as an educational tool, which represents a challenging approach to $21^{\text {st }}$-century education.

These communities are specific environments allowing people to conduct public discussions in virtual spaces (Papacharissi, 2011). Social interaction provides opportunities for people to get acquainted, to become familiar with one another, and to build new knowledge supported by common interests. Such new spaces allow people to interact with those who share their interests and opinions, and to feel part of a community with the same values, goals and behaviors.

From this perspective, a virtual community can be defined around four elements:

(1) A sense of belonging that does not exclude differences among its members but helps to improve the quality of the interactions and outcomes derived from it.

(2) An interaction similar to the "face-to-face" type, organized around daily and common goals essential for this interaction to occur.

(3) An ability to reflect on itself as a group.

(4) Participation in joint tasks that give meaning to their activities.

Without forgetting another important element in this work related to the dual role that discourse has in the said communities (Fiore, 2007), an attempt will be made to define the boundaries and identities of participants and also to preserve horizontality in the joint construction of meanings.

The existence of an online community in the school generates an open environment where students interact, collaborate, and exchange all their aims and reflections developed in the classroom (Renninger \& Shumar, 2002; Schlager, Farooq, Fusco, Schank, \& Dwyer, 2009). In this context, thinking and writing about a video game beginning with personal and collective experiences in an online community of players helps to build situated and shared meanings (Gee, 2008). This form of participation will contribute to discover and reconstruct the key elements that define the video game as a specific semiotic code -from the meanings provided by each participant.

\subsubsection{The video game and its grammars}

This paper regards the video game as a semiotic domain (Gee, 2003), understood as a set of practices that mobilize one or more modalities (oral or written language, images, equations, symbols, sounds, gestures, figures, artifacts, etc.) to communicate different types of meanings.

Any domain can be viewed internally, as a set of content and rules (internal grammar), or externally, in terms of people participating in a set of social practices (external grammar):

Semiotic domains have what I call design grammars. Each domain has an internal and an external grammar. By an internal design grammar, I mean the principles and patterns in terms of which one can recognize what is not acceptable or typical content in a semiotic domain. By an external design grammar, I mean the principles and patterns in terms of which one can recognize what is and what is not an acceptable or typical social practice and identity in regard to the affinity group associated with a semiotic domain. (Gee, 2007, pp. 28-29)

It is important to take into account that the grammars which define a semiotic domain are mutually related. The set of social practices and identities shared by the people who use the same code help to design their external grammar which in turn influences the construction of their internal grammar. Integrating an online community into the classroom as part of its external grammar has allowed generating new forms of literacy through an explicit awareness of the language and discourses present in the game.

For us, language must be understood as a form of expression and speech, as a system that transmits ways of thinking, of seeing the world, which makes sense in certain cultural contexts. It is necessary to distinguish between the utilization of the term speech when considered as an abstract concept and when used to refer to a social phenomenon, and its more specific utilization linked to specific examples. For example, in the case of The Sims 3, talking about speech involves considering the video game as a means of communication, just like film or television. In any event, discovering its meaning depends on the context in which the player is located. It will be different if the person is, for example, a novice or an expert, if he/she participates in the community or if he/she does not even know that it exists.

The speech present in video games can be considered in relation to the social situations where it appears (Van Dijk, 1997), affecting not only the written speech but also the audiovisual (Lacasa, 2011). Speech refers to different ways of expression involving an interaction between people. When talking about video games, two types of interaction can be highlighted: 
(1) The relationship between the game designer and the player.

(2) The relationships between the player and the game universe that goes beyond the screen.

The player becomes immersed in an activity -not only individual, but also social- which is developed, among other possibilities, through online communities and fan sites (Cortés, García-Pernía \& Lacasa, 2012) generated around specific games where different players share experiences and construct meanings together.

The use of an online community (forum) and a game (The Sims 3) in a high school classroom has allowed us to introduce the students to a reflective use of technology, considered as an instrument with which they can express themselves (Gee, 2003; Hin \& Subramaniam, 2009; Jenkins, 2006). Our paper explores how students become aware of the internal game grammar with the support of an external grammar; in this case, a forum where players share the experiences and knowledge gained during play sessions in the classroom.

\subsection{Discovering The Sims together}

Regular players are well aware that playing involves taking an active part in the game, knowing its contents and rules, making decisions and solving problems to continue playing (Johnson, 2005; Lacasa, Méndez, \& Martínez, 2008). Mastering these aspects is part of the literacy process that allows the player to confront the content and design of the game critically while enacting conscious problem-solving processes.

\subsubsection{Simulation video games from their content and design}

Video games have different characteristics which define them as part of specific 'genres' (Buckingham \& Scanlon, 2003), namely: action, strategy, sports, adventure and simulation (Pelegrina, 2003; Poole, 2000; Wolf \& Perron, 2003). Special attention is paid to the latter here because it is the kind of game used in this research work.

In simulation games, the characters' actions simulate real situations. This genre includes the so-called social simulation games, which allow players to create a virtual world where they live a parallel life according to their wishes. Through a series of qualities (Figure 2), these games provide the player with a realistic environment structured around a narrative that he/she explores, discovers and, therefore, defines and creates.

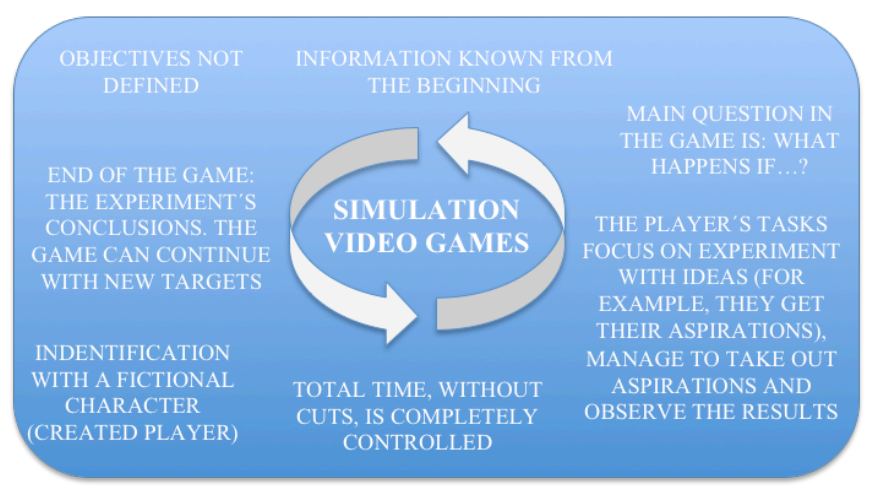

Figure 2. Qualities defining simulation video games

Players can create virtual worlds where they can reflect the reality around them or, on the contrary, very different worlds in which they have the opportunity to experience a new life. People can create a new virtual identity through game characters.

Simulation video games offer the chance to experience both the events that happen in the game and the consequences of the player's actions and decisions. The social nature of these games offers a chance to learn behaviors and values to live within the game and outside of it. A game of this type triggers social relationships between players while they have fun and learn (Bartolome, 1999)

\subsubsection{Representing the problem and sharing the solution}

Video games urge players to learn and think differently. Working with these technologies allows not only for skill development, but also for the possibility of working on skills related to problem-solving and decision-making (Monjelat \& Méndez, 2012). When students think and talk about the video game inside and outside the classroom, in the forum, they become aware of the rules (the limits imposed by the system and designed by its creators) and, thus, become capable of controlling them and make progress in generating problemsolving strategies.

Every person approaches this process differently (Lacasa, 2011), every player has a different way of approaching the game and this reflects personal mental processes and ways of imagining, inferring, making decisions or even remembering previous experiences with other video games to overcome new challenges.

Solving a problem requires building an internal representation about it, analyzing the cause which generates it, and developing a visual representation of the situation and the objects in the scenario. After considering the problem, it is necessary to devise the way to deal with it, to assess its effects, and to become aware of the strategies to solve it. Strategies are defined as paths to find the solution, and when people pose them consciously, one can talk about planning. Facing a problem and finding an appropriate strategy can involve many different paths and methods (Lacasa, 2011): trial and error, proximity, fractionation, etc. Each of them provides the player with a different approach to the problem and its solution. Following one strategy or the other changes the course of the game as well as the player's actions.

In short, learning and becoming aware of the decisions made opens up a world of possibilities in which the player will be aware of his/her own actions which, in turn, can help him/her to use the same strategy for new problems arising in the same game or in a similar one. This awareness of responsibility for their actions during the game and the decisions taken to solve the problems can be gained either individually or together, when using a tool such as online communities of players.

\subsubsection{Collective awareness, the value of virtual communities}

As seen before, problem-solving is not a purely individual act. Due to its nature, it involves emotions, social relationships, and a social structure (Rogoff, 1993). From this perspective, problem-solving depends on the resources and support provided by the people with whom one interacts through social practices. The practice developed in virtual communities motivates players to resort to the representations provided by other players whenever they cannot find a solution or feel blocked. Sharing in a community generates multiple representations of problems and helps to understand different perspectives. 
The possibility to dialogue in the forum with peers allows players to share both their experiences and reconstruct the representation of the problems encountered during the game and strategies to solve them through an online conversation. All trial and error tests, previous knowledge and the small goals or subgoals reached by every player are at the service of the group. Through their messages, they show the awareness of their knowledge not only of the game but also of the problems and the strategies adopted to overcome them. From this perspective, introducing this practice in the school facilitates the emergence of a true participatory culture where it is possible to trigger new literacy processes.

However, does the introduction of these practices suffice to achieve true literacy? Certainly not, two elements are needed to achieve this. First, it is necessary to choose good games whose internal design stimulates thinking in multiple directions, as is the case of The Sims 3. Second, a scenario must be designed where participants can reflect together, talk, share solutions and even learn and teach specific knowledge transfer to reach others.

\section{METHODOLOGY}

This paper adopts a qualitative research perspective understood as a situated activity that locates the observer in the world (Denzin \& Lincoln, 2011) as immersed in the processes of meaning construction. The same as in previous studies of this research group (Lacasa \& Grupo Imágenes, Palabras e Ideas, 2009; Lacasa et al., 2011, 2012), an ethnographic point of view is used (Hamera, 2011) -in this case a virtual environment that combines narrative and analytical interpretations (Bal \& Boheemen, 2009).

The video game workshop was carried out in two clearly differentiated scenarios: the classroom and the online community. In this article, the goal focuses on analyzing the second scenario, i.e. the forum where the students participated. Following educational sociolinguistics (Gee, 2010; Gee \& Hayes, 2011) closely, some methodological premises were adopted:

(1) First, the focus was not placed on isolated individuals but on activities organized by cultural patterns that took place in specific environments. Our interest referred to the activities carried out by the students and their teacher in the social network (forum). The adoption of this methodological perspective allowed us to explore the goals which give meaning to these activities associated with social and cultural processes.

(2) Second, in order to analyze patterns of activity, the contributions of each participant must be considered as dependent on one another and on the context where they emerge.

\subsection{Context and participants}

The data presented were collected as part of the project "Los videojuegos. Educar en una sociedad global [Video games. Educating in a global society]" (www.aprendeyjuegaconea.com), conducted during the 20102011 academic year. More specifically, the experience presented took place in a Madrid public secondary school with a group of second year students (aged 12-13) and their English teacher. Analyzing a single group of students, from an ethnographic point of view, is to focus our interest on the process rather than on the statistical significance of the sample.

The group under analysis included 27 students, 13 girls and 14 boys. Most of them were used to playing video games, but only three of them had previously played The Sims 3. The teacher was highly experienced in her subject (English) and, like her students, she was also a regular gamer, even though she had never played this specific game before.

\subsection{The instruments}

\subsubsection{The video game}

Our research work was based on The Sims 3 -part of The Sims saga. This game allows players to design a character and create a virtual scenario similar to the real world or totally fictional (a city, district, family, etc.). The player is in a world of rules and must make decisions, act and behave within certain parameters, reaching certain aspirations. He/she is forced to think according to the rules. Some of these rules are specific to this game and others are common to all games.

Table 1. Reconstruction of the workshop

\begin{tabular}{ll}
\hline INSIDE THE CLASSROOM: Game sessions \\
$\begin{array}{l}\text { Session 1: Talking and } \\
\text { motivating }\end{array}$ & $\begin{array}{l}\text { At the beginning of the workshop, the teacher introduced her students to the video game. Then, she explained } \\
\text { what they had to do: choosing characters and designing a virtual life. }\end{array}$ \\
$\begin{array}{l}\text { Sessions 1 to 3: Playing the } \\
\text { video game }\end{array}$ & $\begin{array}{l}\text { The students played The Sims 3. First, they created their characters by deciding on physical appearance and } \\
\text { personality. Then, they had to build a house to live in. In order to do this, they made decisions together and } \\
\text { solved the game's challenges collaboratively. }\end{array}$ \\
$\begin{array}{l}\text { When each session ended, each group presented what they had done with their Sims. They shared their } \\
\text { problems. Oral conversations helped them to become aware of their actions during the game, and to overcome } \\
\text { the challenges and strategies to solve specific problems. This approximation to the elements, which define the } \\
\text { rules of the game, was complemented by activities outside the classroom (participation in the forum). }\end{array}$ \\
$\begin{array}{ll}\text { OUTSIDE THE CLASSROOM: Online community (forum } \\
\text { content }\end{array}$ \\
$\begin{array}{l}\text { Representation of the problems } \\
\text { and seeking solutions }\end{array}$ & $\begin{array}{l}\text { Students pooled their ideas for The Sims 3. Through their posts, they shares the elements that make this type of } \\
\text { game and the rules that define their design and shape their actions in the game. } \\
\text { about the most effective strategies to overcome them. }\end{array}$
\end{tabular}




\subsubsection{The Sims 3 workshop}

The research team -along with the teachers - designed the video game workshop. The aim of the teacher focused on the development of English language skills for the students to express themselves both orally and in writing in fictional worlds. This article is based on the research team's goals, focused on analyzing how the players discover the internal game grammar. On the one hand, attention is paid to the contents and design that define it and, on the other, to the representations made of the problems encountered during the game and the strategies to solve them.

As mentioned above, the workshop was conducted in two scenarios, both inside and outside the classroom. (Table 1).

At first, the students played The Sims 3 in small groups inside the classroom (during 10 sessions, 50-minute long each). Then, they participated in the online community Jugar $y$ Aprender (Play and Learn) (http://uah-gipi.org/red/), created by the researchers to support game sessions and facilitate joint reflection. The use of this tool in a school context creates an educational space where students interact around common goals defined in the classroom (Cortés, García-Pernía, \& Lacasa, 2012). This online community was structured in different sections: a section called My Desk where students could create their own space to identify and introduce themselves; a contact section to connect with peers; and also several sections of dialogue and reflection through blogging, forums and chats.

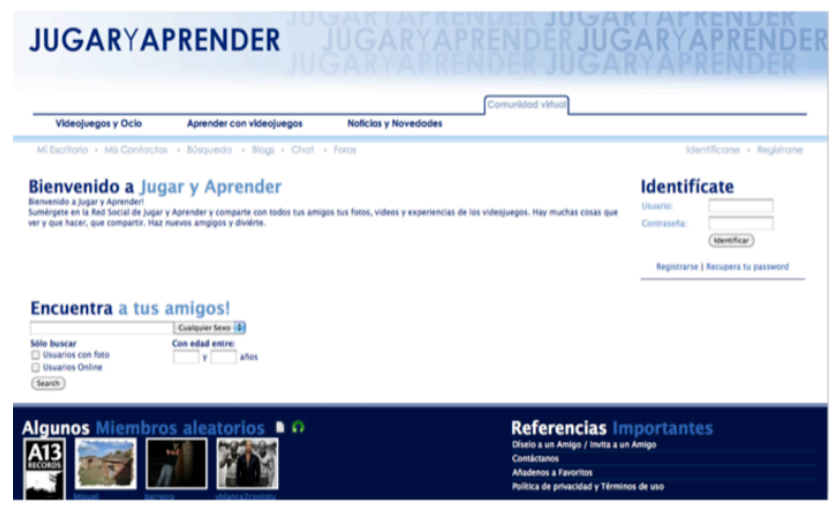

Figure 3. The social network Jugar y Aprender [Play and Learn]

This paper specifically analyzes the virtual conversations conducted by a second group of students in the forum (from 2011-04-01 to 2011-05-26), where they used English as their language and issued a total of 139 messages.

\subsection{Procedure. Data collection and analysis}

The analysis of the forum, the main topic of this article, was conducted using the conversation transcripts, which permitted to analyze the discursive processes that took place in the online environment.

The approach to the data was inductive. From the speeches of the participants in the forum, a system of categories was developed that allowed the examination of the data obtained by applying it to all interventions. The software program Atlas $\mathrm{Ti}$ was used to perform this analysis.

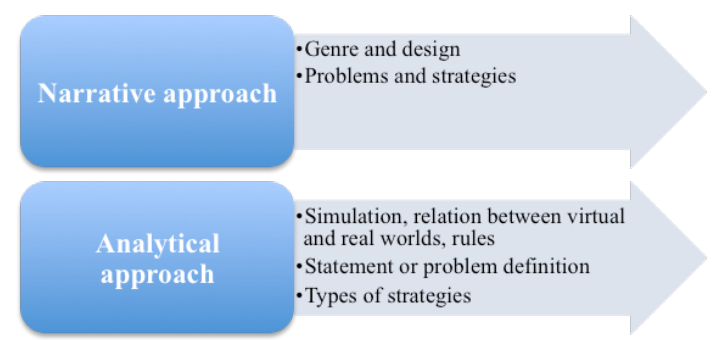

Figure 4. Categories for analysis

The developed category system includes two approaches: a more general, narrative one; and a more specific and analytical approach that explains the previous one. In the first, there are two categories which permitted to classify messages into two blocks: one referring to ideas about the game and focused on the elements that define its genre; and the other related to the representation of the problems that players face while playing. The second approach, more analytical, interpreted the messages of these two blocks from the meanings shared among participants during the conversational process.

\section{MAIN RESULTS AND DISCUSSION}

Seeking to explain the results, a selection was made of some messages that significantly reflect issues relevant to the analysis. Exploring these messages, will enable us to show the processes carried out by students -related to the shared representation of the game and the elements that define its grammar.

\subsection{Content and design of the game}

This section describes how students become aware of their ideas about the game and how they share them through their participation in the forum. Analyzing messages allowed us to discover that there are two characteristics which best define The Sims game for these young players. The first one refers to the content or focus of this type of video game; and the second has to do with the elements which define design.

Being a social simulation game, the content is related to the creation and control of a fictional world by the player. The interventions in the forum reveal how the universe created in virtual reality interacts with the experiments carried out in the real world and the different identities that the player assumes in both worlds.

Several messages were selected to prove this idea. In the first fragment, the video game is defined by one of its most characteristic features, the ability to simulate real life.

Transcript 1. Virtual world vs. Real world

- Monii (03/04/2011 16:12): Hello!! I think that The Sims 3 is a game in which, in a way, is reflected the real life and that we can experience things that maybe will happen to us in the future because: we have to take care of the things of the house, take care of ourselves because if we don't do that we die, we have to interact with other sims. ${ }^{1}$

This student emphasizes how The Sims allows her to experience both simulated real-life situations and situations that she has not experienced yet but which are possible later in life. Being responsible for her home and herself, she tests her ability

\footnotetext{
${ }^{1}$ Please note that all transcripts are a true representation of what the students wrote themselves as non-native speakers immersed in a secondlanguage acquisition process.
} 
to live these situations in the safe and secure space offered by the game.

- Miguel (04/04/2011 18:47): Hi, I think that the game is very funny because you care your sim. For example another day my sim almost died because was hungry and $\mathrm{i}$ has to travel to the supermarket. It's very entertaining but has extrange thinks like the thinks that said sergio, fran and vladut that speak a extrange lenguaje that anyone can understand and were better if the sims speak my lenguaje and can understand.

This message highlights another feature of this type of game: the ability to play God and control an avatar's life, being responsible for its care and survival. With this message, the author brings into focus the relationship between the player and the character created, which is crucial to understand this type of game where the player has a dual identity $-\mathrm{a}$ real and a virtual one, the latter represented by the avatar- (Gee, 2008).

This message additionally reveals a second feature supplementing the representation that players have of the Sims: game design. In his speech, this student mentions the elements imposed by the designer of the game. In particular, he criticizes the incomprehensible jargon of The Sims and suggests it would be better to reproduce "real language". The cause of his displeasure probably lies in the fact that this jargon prevents him from faithfully reconstructing real life. This feature of the game creates an imbalance in the figured world (Holland, Lachicotte, Skinner, \& Cain, 2003) between the characters, the fictional world where they are immersed, and the goals of the player, in this case simulating real experiences.

In line with this, the following message is another example of how the players become aware of game design and how it determines theirs actions and experiences during the game:

- Celiuki (10/04/2011 21:54): Yes, is sometimes boring but I like the mistakes thar are: for example when you are in the road and a car is coming pass though your body. or when talk their "language" that is like chinese or when your sim can't pass through a door that begin to spin or more things.

Unlike the previous transcript, the author indicates that the strange language, along with other items that are far from the real world, seems amusing to her. This brings us to another typical feature of these games, one which has to do with the possibilities of constructing a fantasy world where impossible things become possible in the game thanks to fictional eligibility. Impossible and ineligible actions can be carried out, in this case physically, in the everyday world of the player through these creations (Holland et al., 2003).

In both messages, the students highlight design elements which form part of the fictional world and interact with the player's actions and options. The forum interventions help to establish a dialogue between the player, the characters and the designer, all of them elements which define the game and make it possible.

\subsection{Problem representation}

Another aspect reflected on the forum analysis (Table 2) was the ability shown by the players to build and share the representation of the problems they had while playing the game.

The following table classifies the problems encountered in the forum and their connection with the goals of the game.
Table 2. The problems discussed in the forum.

\begin{tabular}{|c|c|c|}
\hline Problem & Description & Example \\
\hline $\begin{array}{l}\text { Related to the } \\
\text { characteristics of } \\
\text { the avatar }\end{array}$ & $\begin{array}{l}\text { Posing questions about } \\
\text { how to change the } \\
\text { physical appearance of } \\
\text { the avatar. }\end{array}$ & $\begin{array}{l}\text { How to become an } \\
\text { adult } \\
\text { How to become more } \\
\text { muscular }\end{array}$ \\
\hline $\begin{array}{l}\text { Related to the } \\
\text { conditions that } \\
\text { help the survival } \\
\text { of the avatar }\end{array}$ & $\begin{array}{l}\text { Doubts arise concerning } \\
\text { how to modify or create } \\
\text { the conditions necessary } \\
\text { for the avatars to live } \\
\text { and grow }\end{array}$ & $\begin{array}{l}\text { How to make the } \\
\text { character eat } \\
\text { How to prevent the } \\
\text { character from } \\
\text { getting sick and die } \\
\text { How to make the } \\
\text { character work and } \\
\text { earn money }\end{array}$ \\
\hline $\begin{array}{l}\text { Related to the } \\
\text { features of the } \\
\text { game and its } \\
\text { design }\end{array}$ & $\begin{array}{l}\text { Doubts arise concerning } \\
\text { the elements and the } \\
\text { rules imposed by the } \\
\text { design and determining } \\
\text { the player's actions and } \\
\text { the construction of the } \\
\text { fictional world }\end{array}$ & $\begin{array}{l}\text { How to control the } \\
\text { passage of time } \\
\text { What the function of } \\
\text { certain symbols of } \\
\text { the game is } \\
\text { How to start a new } \\
\text { game or create a new } \\
\text { Sim }\end{array}$ \\
\hline
\end{tabular}

The next examples discussed below show different degrees of development in the representation of problems. A distinction can be made between messages that emphasize what prevents the player from driving toward his/her goal and those denoting greater complexity. In the following messages, as well as indicating the obstacle, students highlight the strategies that they have tried in order to advance in the game or even anticipate a hypothesis which could be the solution.

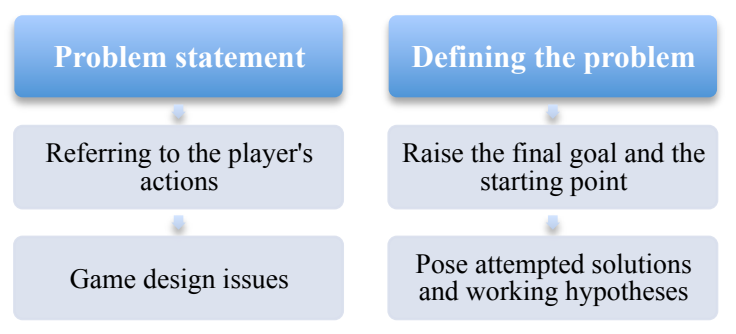

Figure 5. Problem representation. Categories for analysis

Some examples of the first type were initially shown where the message merely states the problem in a question addressed to other participants in the forum.

\section{Transcript 2. Stating problems}

- Cee (04/04/2011 21:46): I have a question: if you are out of the house after the curfew, what can happen?

- Miguel (05/04/2011 18:37): I has a question. When you has the family, during you are playing you can created new sims or change something of the sims that now are created? Good Bye. Miguel

Both focus on the player's actions as a problem in two ways. On the one hand, they ask about the consequences of a certain action in the forum (leaving the house during curfew) and, on the other, they determine which actions to take in order to achieve a specific purpose (creating a new Sim or changing its appearance). Both ideas are a mystery and a problem for further progress in the game. 
Unlike these two messages, the following one states the problem but is not focused on which action to take or what the consequences could be if one option or the other is taken, but on the functions of an element imposed by the game designer.

\section{Transcript 3. Operates}

- Mesa (06/04/2011 16:34): I have a question, that is that the points that the game give you when you talk with some prople or you do other thinks, I don't know the use that we can give to that points. If you can answer the question... See you. Edu

The problem with this player is that he doesn't know the role of the points in the game and the rule that determines their usefulness. He knows how to obtain them, but he doesn't understand what they are used for.

Continuing with the analysis, the messages which are presented next allow us to explore new forms of problem representation, depending on the player posing the problem and the stage he/she is at. States no longer appear formulated as questions, but as more complex representations that indicate the elements which constitute the essence of the problem and help to define it better:

- Celiuki (10/04/2011 21:54): Ah! one thing! How can I make me an adult? because I am a teen and i don't want because I want to be thief and... i can't. Celiuki

In this message, the problem is how to turn the avatar into an adult. Unlike previous posts, the problem is better defined. In addition to stating the problem (how can the Sim become an adult), she also describes its current state (the avatar is a teenager) and how this fact prevents her from reaching her goal (to become a thief). This analysis shows how, through her message, the author has been able to define various elements of the problem: the goal she wants to achieve, the starting point, and the implicit rules of the game -which, in this case, prevent non-adult characters from performing certain actions.

A further exploration of the forum provides messages where more complex problem-definition processes are present:

- Miguel (04/04/2011 18:47): I has a question, the sims of my group doesnt eat because the fast food are finish. I went to the supermarket and now we has food but we didn't know how eat because the sims didn't eat. It's necessary that the sims have to learn to cook or there are a option to eat without are necessary to know how cook?

In this new message, in addition to the final goal (to feed the avatar), and the starting point (no food), the player describes the actions carried out as well as the strategies used to solve the problem (going to the supermarket and buying food). Finally, he anticipates a hypothesis (it is necessary to learn how to cook) and requests confirmation from the forum.

The player who wrote the following message doesn't know how to feed his avatar either. He mentions a strategy that was successful for his purpose (going to a restaurant), but he does not think it's the most effective one (it's too expensive), so he asks the forum for a better solution:

- 2avladut (05/04/2011 19:55): I was playing last day in M.A.E. and we don't know how to eat beacuse we buy food but we dont know how to eat it. And in the fridge we select cereals, ice cream, soup, juice or someting like that and $i$ can't eat. Luckly i went to a restauran and I didn't die but you know... RESTAURANT $=$ MONEY and is very expensive. Help me please!
The messages analyzed so far have shown us the initial phase by placing players before a game problem: definition and organization of information. The next section will focus on explaining another phase that makes up the problem-solving cycle (Sternberg, 2009) and refer to the construction of strategies to overcome them.

\subsection{On the game strategies}

Having a forum to share their experiences as players allowed students to build a common representation of their problems and share different strategies to solve them. The same as in the analysis above, varying degrees of complexity can be appreciated in this case too.

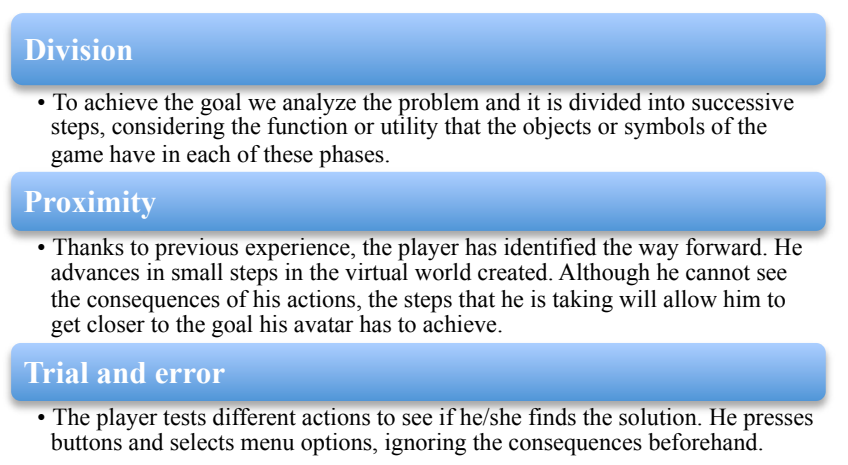

Figure 6. Strategies to solve problems. Categories for analysis

The analysis will start with a conversation between two students. The first participant, Nuria, asks her peers in the forum how to control the passage of time and stop it. She complains that, when she starts to play, time goes by fast and she can't control it. In this case, a rule imposed by the game design conditions the fictional world and the characters that inhabit it. When faced to this problem, players can't do anything about it because they do not know how this design element works.

Transcript 4. Over time a rule imposed in the game

- Nuria (12/04/2011 19:12): Hi! I have a question releated with the thing that said Mónica, about how to stop the time, my question is that when $i$ am playing with my sim the time start to go very quickly and i don't doing anything, how I can stop the time? If someone know please tell me. Bye. Nuria.

In the following message, Celia offers a strategy to overcome the problem posed by her peer. Analyzing it allows us to check that she is not sure about the solution offered (again, I think ...). It is a strategy that she just tried, and although it worked for her, she does not know if the strategy will work for Nuria as well. The proposed strategy is based on trial and error and provides an example of a simple approach to solve the problem.

- Celiuki (12/04/2011 21:54): Hi Nuria, I THINK that pass this, because you give the button the Nunchuck (or whatever) I think that is the " $\mathrm{C}$ " or the "Z" (that are in the back) and I proof this today, and goes quickly. Os I think that is this I hope that this information helps you. (Repeat I THINK). Celiuki :3

Throughout the analysis, it has become visible how talking about problems and getting help to overcome them forces students to think about the strategies that they use throughout the game, even if they are not aware of them. The examples below 
show how some students become aware of the strategies adopted and their degree of complexity when trying to help their peers.

In the next dialogue, Paul poses a problem: he doesn't know how to find a job for his Sim. Two different colleagues in the forum offer him a solution.

Trancript 5. How I can find work for the Sim?

- Jordan (08/04/2011 17:55): Hello to all people!!! I have a question, How can I put an adult person to work? Thanks. Pablo.

- Mesa (09/04/2011 09:45): Pablo, if you want to take a job in the city there are some buildings to take a job such us policeman or the opposite, a villane I think that if you put the top view there are different options in the left down of the screen. I don't know what options are but I think that one of those have to be of buidings to do job. Edu.

- Monii (09/04/2011 17:18): Hi Pablo. Edu is right, when you want to get a new job, you have to press the button 2 of the Wii remote control and instantanely will appear a map of the city. Then, in the bottom corner of the map, there are some options and you have to press the button that puts "empleos". Next, on the map will appear to you some squares with toons. Then choose the one you want and and press "ir". A taxi will come to pick and take you to that place. Next, press the building and different options appears. One of them is to get a new job. Press it and and automatically you get that job. See you on Monday, MONI.
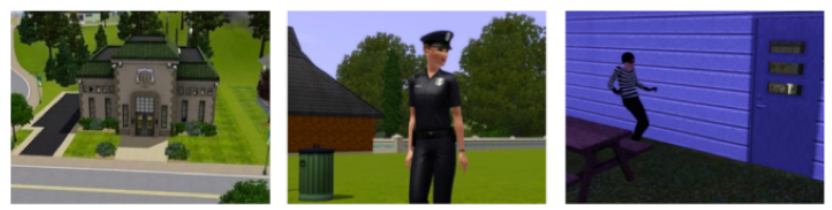

Figure 7. A job for The Sims

The analysis of the three preceding messages reveals that the strategies suggested in each of them are different and reflect different ways of defining the problem and its solution. In Edu's message, the intervention begins by dimensioning the problem: for a character to work, he/she needs to find a job first. Once the goal is explicit, someone refers to specific elements offered by the game to find work: buildings. Some of them, such as the police station, are linked to police work and its opposite (thieves). Finally, someone just offers a hypothesis on possible actions to solve the problem related to the operators offered by the game: I think that if you put the top view there are different options in the left down of the screen. These actions have to do with specific decisions which allow the player to take specific steps in order to achieve a goal. If this fragment is analyzed considering the strategies offered to solve the problem, it could be described as a proximity strategy. There is an advance towards the solution, but the explanation is simple and undeveloped. The solution comes in two steps: first, to approach the buildings and, second, to choose an option from the menu.

Unlike Mesa's intervention, Monii's contribution reflects a more elaborate strategy, one which is not limited to suggesting actions to reach the goal but divides the problem into simpler parts or phases that correspond to successive screens as the player moves closer to the solution. The player has used a fractionation strategy by identifying partial goals necessary to achieve the final goal and solve the problem.

\section{CONCLUSION}

This whole article has shown the results obtained after designing an educational setting in which high school students dialogued about their experience with The Sims in an online community. Previous works (Lacasa, Méndez, \& Martínez, 2008; Méndez, García-Pernía, \& Cortés, 2011) had already described how collaborative play and dialogue, before and after games, helped to generate new literacy processes around video games. In our experience, classroom dialogue was complemented with an online community, a scenario typically used by players to share their experiences and build knowledge together outside the school (Papachasi, 2011). In this context, the participation of students in the forum after playing in the classroom changed the learning process and turned it into a collective process where thinking and writing about one's own experiences -both personal and collective ones- helped to build located and shared meanings about the game.

The analysis of 'talks,' conducted from a qualitative and ethnographic approach, showed -as it had already happened in other studies (Barton, 2007; Dobson \& Willinsky, 2009; Fiore, 2007)- how students discovered and reconstructed the keys that define the game as a semiotic code from the meanings provided by each one of them (Dobson \& Willinsky, 2009). In this sense, the talks reflected how participation in a social practice -which forms part of the external game grammar- made players become aware through the collective discourse of internal grammar that characterizes a simulation video game like The Sims. The most significant findings can be grouped together around three ideas:

- Through their messages in the forum, students shared their thoughts about the game with other players and, between them, reconstructed the system of meanings related to the content and design elements that define the simulation genre.

- When writing on the forum and using the speech code characteristic of this medium, collaborative learning was favored, sharing the problems encountered during the game as well as the strategies used to solve.

- In addition to this, the social network facilitated the emergence of a more horizontal knowledge, where individual contributions helped to develop of a joint representation of the problems and strategies adopted to solve them, which became increasingly complex and elaborate.

These results show some of the benefits of using communication tools in classrooms. A social network related to a commercial video game turns the school into a place where new processes of literacy become essential for citizenship in the 21 st century within the framework of a participatory culture.

\section{REFERENCES}

Bal, M. \& Boheemen, C. V. (2009). Narratology: Introduction to the Theory of Narrative (3rd ed.). Toronto: University of Toronto Press.

Bartolome, A. (1999). Nuevas tecnologías en el aula. Guía de supervivencia. Barcelona: Graó-ICE, Universidad de Barcelona.

Barton, D. (2007). Literacy: An Introduction to the Ecology of Written Language (2nd ed.). Oxford: Blackwell Publishing.

Buckingham, D. \& Scanlon, M. (2003). Education, entertainment, and learning in the home. Buckingham: Open University Press. 
Cortés, S., García-Pernía, M. R., \& Lacasa, P. (2012). Videojuegos y Redes Sociales. El proceso de identidad en Los Sims 3. RED. Revista de Educación a Distancia (33), 1-18.

Denzin, N. K., \& Lincoln, Y. S. (2011). Introduction: the discipline and practice of qualitative research. In N. K. Denzin \& Y. S. Lincoln (Eds.), The SAGE Handbook of Qualitative Research (4th ed., pp. 1-21). Thousand Oaks, Calif. London: Sage Publications.

Dobson, T. M., \& Willinsky, J. (2009). Digital literacy. In D. R. Olson \& N. Torrance (Eds.), The Cambridge Handbook of Literacy (pp. 3-22). Cambridge University Press: Cambridge, NY. doi: 10.1017/CBO9780511609664.017

Fiore, F.D. (2007). Communities Versus Networks. The Implications on Innovation and Social Change. American Behavioral Scientist, 50(7), 879-896. doi: $10.1177 / 0002764206298311$

Gee, J. P., \& Hayes, E. R. (2011). Learning and language in the digital age. New York: Routledge.

Gee, J. P. (2010). How to do a discourse analysis: a toolkit. New York: Routledge.

Gee, J. P. (2008). Video Games and Embodiment. Games and Culture, 3(3-4), 253-263. doi 10.1177/1555412008317309

Gee, J. P. (2007). What Video Games Have to Teach Us About Learning and Literacy. Second Edition: Revised and Updated Edition [Paperback]. New York: Palgrave Macmillan.

Gee, J. P. (2003). What Video Games Have to Teach us About Learning and Literacy. New York: Palgrave Macmillan.

Hamera, J. (2011). Performance ethnography. In N. K. Denzin \& Y. S. Lincoln (Eds.), The SAGE Handbook of Qualitative Research (4th ed., pp.317-330). Thousand Oaks, Calif. London: Sage Publications.

Hin, L. T. W., \& Subramaniam, R. (2009). Handbook of research on New Media Literacy at the K-12 Level: Issue and Challenges. Hershey, New York: Information Science Reference (IGI Global). doi: 10.4018/978-1-60566-120-9

Holland, D., Lachicotte, W., Skinner, D., \& Cain, D. (2003). Identity and agency in cultural worlds. Cambridge, MA: Harvard University Press.

Jenkins, H., Clinton, K., Purushotma, R., Robison, A. J., \& Weigel, M. (2009). Confronting the Challenges of Participatory Culture: Media Education for the 21st Century. Cambridge, MA: The MIT Press, MacArthur Foundation.

Jenkins, H. (2006). Convergence culture where old and new media collide. New York: New York University Press.

Johnson, S. (2005). Your Brain on Video Games. Could they actually be good for you? Retrieved from http://discovermagazine.com/2005/jul/brain-onvideogames\#.UgpjyeCEmpo

Lacasa, P. (2011). Los videojuegos: Aprender en mundos reales y virtuales. Madrid: Morata.

Lacasa, P., Méndez, L., Cortés, S., Martínez-Borda, R., García-Pernía, M. R., del-Castillo, H., \& Casas, X. (2011). Redes Sociales y Videojuegos. Madrid: Electronic Arts de España / Universidad de Alcalá.

Retrieved from

http://www.aprendeyjuegaconea.com/informe/2011EA_UAHV8/Bie nvenida.html.

Lacasa, P., Méndez, L., Cortés, S., García-Pernía, M. R., Monjelat, N., \& Martínez, R. (2012). Videojuegos y Diversidad. Madrid: Electronic Arts de España / Universidad de Alcalá. Retrieved from http://www.aprendeyjuegaconea.com/informe2/2012_Diversidad/Bie nvenida.html.

Lacasa, P. \& Grupo Imágenes Palabras e Ideas. (2009). Videojuegos en el Instituto. Ocio digital como estímulo en la enseñanza. Madrid: Electronic Arts de España / Universidad de Alcalá. Retrieved from www.aprendeyjuegaconea.com/files/informe_UAH_2009.pdf.

Lacasa, P., Méndez, L., \& Martínez, R. (2008). Developing new literacies using commercial videogames as educational tools. Linguistics \& Education, 19(2), 85-106. doi 10.1016/j.linged.2008.02.001

Méndez, L., García-Pernía, M. R., \& Cortés, S. (2011). Alfabetizaciones digitales. Los videojuegos como herramienta educativa. In M. SenraVarela (Ed.), Ambitos y estrategias en la intervención socioeducativa con menores (pp. 347-386). Madrid: Editorial Sanz y Torres.

Méndez, L., Lacasa, P., \& García-Pernía, M. (2013). Digital communities and videogames as educational tools in participatory culture. Int. J. Social Media and Interactive Learning Environments, 1(2), 145-163. doi: 10.1504/IJSMILE.2013.053602
Monjelat, N., \& Méndez, L. (2012). Problem solving Processes and Videogames: The Sim City Case. Electronic Journal of Research in Educational Psychology, 10(3), 1493-1522.

Olson, D. R., \& Torrance, N. (Eds.) (2009). The Cambridge handbook of literacy. Cambridge, N.Y.: Cambridge University Press. doi: $10.1017 / \mathrm{CBO} 9780511609664$

Papacharissi, Z. (2011). A Networked Self: Identity, Community and Culture on Social Network Sites. New York: Routledge.

Pelegrina, T. (2003). Los videojuegos: qué son y cómo nos afecta. Barcelona: Ariel.

Poole, S. (2000). Trigger happy: The inmer life of videogames. London: Fourth Estate.

Renninger, K. A., \& Shumar, W. (2002) Building Virtual Communities: Learning and Change in Cyberspace. Cambridge, UK / New York: Cambridge University Press. doi: 10.1017/CBO9780511606373

Rogoff, B. (1993). Aprendices de pensamiento. El desarrollo cognitivo en el contexto social. Barcelona: Paidós.

Schlager, M. S., Farooq, U., Fusco, J., Schank, P., \& Dwyer, N. (2009). Analyzing online teacher networks: cyber-networks require cyberresearch tools. Journal of Technology Education, 60(1), 86-100. doi: $10.1177 / 0022487108328487$

Sternberg, R. J. (2009). Cognitive Psychology. Belmont, USA: Cengage Learning.

Van-Dijk, T. A. (2000). Discourse as social interactions, Vol. 2 (pp. 1 37). Barcelona: Gedisa.

Wells, G. (1990). Talk about text: Where literacy is learned and taught. Curriculum Inquiry, 20(4), 369-405. doi: 10.2307/1179876

Wolf, M. J. P., \& Perron, B. (Eds.). (2003). The video game theory reader. New York / London: Routledge. 